Emir. J. Food Agric. 2010. 22 (3): 174-188

http://ffa.uaeu.ac.ae/ejfa.shtml

\title{
Influence of Pentakeep-V on the nutrient interaction and availability for tomato production
}

\author{
Mahmoud M. Al-Afifi ${ }^{*}$ and Ali M. Al-Shrouf
}

\author{
Department of Arid Land Agriculture, Faculty of Food and Agriculture, United Arab \\ Emirates University, P. O. Box 17555 Al-Ain, United Arab Emirates
}

\begin{abstract}
A field pot experiment was implemented in the Faculty of Food and Agriculture Farm in Al-Ain area, Abu Dhabi, United Arab Emirates, located in Lat. $24 \mathrm{~N}$ and Long. 56 E with 302 $\mathrm{m}$ altitude during 2007/2008 over four months growing season. The experiment was done to evaluate fertilizer use efficiency, nutrient uptake, and yield of tomato (Solanum lycopersicum) as affected by Pentakeep-V. The experimental design was a split-split plot design with application method as main plot (Foliar application (AM1), Soil application (AM2), and Application rate $(0.01 \%(\mathrm{~L} 1), 0.02 \%(\mathrm{~L} 2), 0.04 \%(\mathrm{~L} 3))$ and time interval as sub plots (One week (W1), two weeks (W2), and three weeks (W3)).A control treatment with zero level $(0.00 \%$, L0) of Pentakeep-V was included for comparison. Results showed all Pentakeep-V foliar treatments showed a significantly $(\mathrm{P}<0.05)$ higher tomato fruit in terms of yield and quality as compared to the control treatment with a percent maximum yield of $146 \%$ of the control treatment. The average yield for the most soil application showed less production compared to control except L1W2 and L1W3 that showed 107.9 and $117.7 \%$ respectively. Also results showed a significant negative tendency for the nutrient availability under soil application treatment compared to the foliar especially in case of phosphorus and micronutrient. L3W1 Foliar application treatment showed the highest significant increase in yield and macro and micro nutrient concentration and uptake for the fruit, stem and roots by using atomic absorption spectrophotometer.
\end{abstract}

Keywords: Tomato, nutrient availability, foliar application, Pentakeep-V, 5-aminolevulinic acid, nutrient uptake, rhizosphere.

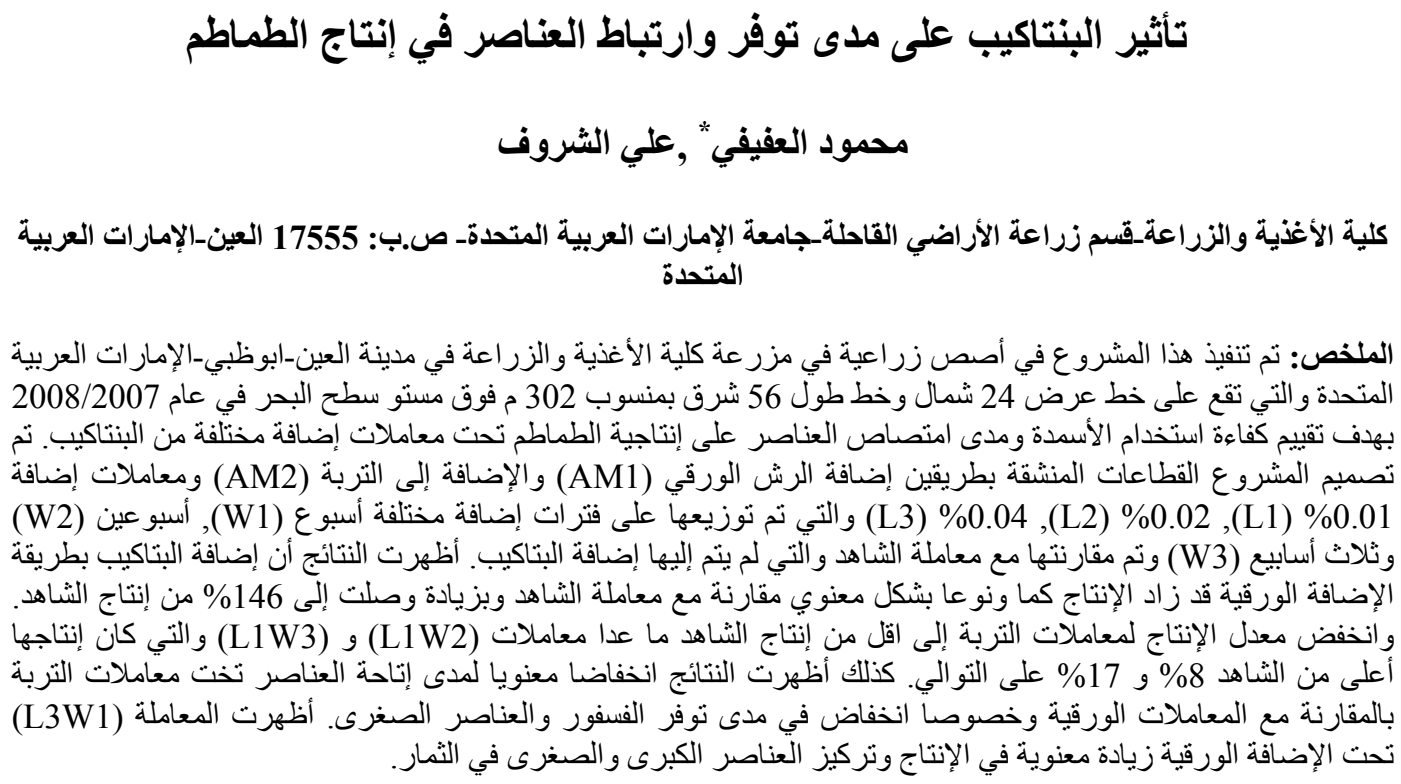

*Corresponding Author, Email: malafifi@uaeu.ac.ae 


\section{Introduction}

Nutrient deficiency is a common nutritional problem in crop production in United Arab Emirates. This problem results in the application of increasing amounts of $\mathrm{P}, \mathrm{N}, \mathrm{Zn}$, Phosphorus (P), Nitrogen $(\mathrm{N})$, Zinc (Zn) and other fertilizers. Soil fertility or the ability to support plant growth, depends on soil physical and chemical properties mainly soil acidity, texture, and nutrient availability (Smaling et al., 1993).

Replacing plant nutrients removed during harvests, and minimizing nutrient losses to the environment are the goals of effective fertilization. Fertilization involves both efficient and balanced fertilization to ensure adequate plant nutrition while maintaining optimum soil fertility levels (Weissbach and Ernst, 1994).

The proper use of fertilizers corrects imbalances or deficiencies in plant nutrients. Integrating fertilizers with manures and leguminous crops within comprehensive plant nutrition systems that are tailored to local conditions is the key to sustainable soil fertility (Hotta et al., 1997).

Since tomato (Solanum lycopersicum) is the one most popular vegetable crop in UAE, goals of effective nutrient management are to provide adequate plant nutrients for optimum growth and highquality harvested products.

Pentakeep- $\mathrm{V}$ is a specially formulated liquid fertilizer, the concentrations of all nutrients in this fertilizer were determined. Also, comparison of plant tissue concentrations at the end of the experiment was done. The fertilizer contains both macro and micro elements needed for plant growth and healthy development. This ensures maximum nutrient uptake and higher plant yield.

According to the provider (Cosmo Oil Co. Ltd.), Pentakeep-V is a fertilizer that is contain ALA, nitrogen, magnesium, manganese, boron, micronutrients, the Pentakeep-V promotes plant photosynthesis, water and fertilizer uptake, increases of tolerance to environmental stress. So this work evaluates the growth and yield of tomato (as one of the most popular vegetable crop in UAE) to the application of Pentakeep-V.

The main objective of this experiment is to evaluate fertilizer use efficiency, nutrient uptake, and yield of tomato as affected by selected rates of Pentakeep-V.

\section{Materials and Methods}

A field pot experiment was implemented in the College of Food and Agriculture Farm in Al-Ain area, located in Lat. $24 \mathrm{~N}$ and Long. $56 \mathrm{E}$ at $302 \mathrm{~m}$ altitude during the 2007/2008 growing season.

The experiment design was split-split plot design for each location with 3 replicates (Figure 1). Constant irrigation quantities, qualities, and chemical organic fertilizer application were used for all treatments. The treatments were distributed according to the following:

\section{Application Method as main plot:}

Foliar application (AM1)

Soil application (AM2).

\section{Application rate and interval as sub plots}

Application rate. $\quad 0.01 \%(\mathrm{~L} 1), 0.02 \%$ (L2), 0.04\% (L3)

Application interval. One week (W1), two weeks (W2), and three weeks (W3)

In addition, a eight replicates for the control treatment with zero level $(0.00 \%$, L0) of Pentakeep-V was added for comparison.

\section{Seedling stage}

A seed germination test in the laboratory produced $90 \%$ seed germination. Tomato Seeds (VFN8 var. Netherlands origin) were planted in a special peat soil using a special multi-cell tray in the farm's nursery on December 19, 
2007, before transplant the seedling in the pot.

\section{Soil preparation and experimental layout}

A virgin surface soil collected from the Al-Ain area was used in the experiment. The soil was mixed thoroughly with local manure organic fertilizer by constant soil to fertilizer ratio $2: 1$. Subsequently each pot $(34 \mathrm{~cm}$ diameter) was filled with $25 \mathrm{~kg}$ soil and organic fertilizer mixture. Sixty pots were distributed in split-split plot design (Figure 1).
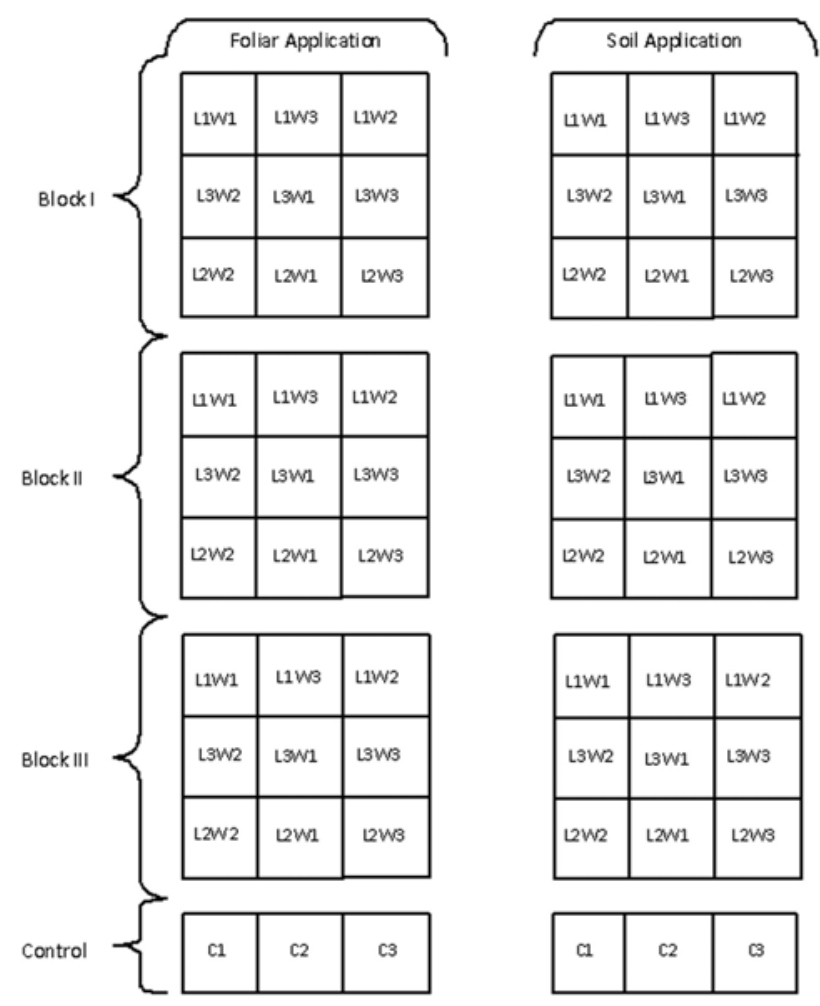

\begin{tabular}{|l|l|l|}
\hline C1 & C2 & C3 \\
\hline
\end{tabular}

Figure 1. Tomato field experimental design.

\section{Lab analysis}

Soil samples as well as irrigation water, fertilizer, and Pentakeep -V were collected for lab analysis before the treatment application to represent the initial nutrient reserve in the soil and the nutrient that will be added through Pentakeep-V, water, and fertilizer.

A soil sample was collected from each pot two times during the season in addition the end-season sampling.

The soil samples were analyzed for field capacity and wilting point using pressure membrane extractor (Topp et al., 1993), bulk density by air Pychnometer (Blake and Hartge, 1986), soil reaction with pH-meter for 1:2.5 soil extract
(Thomas, 1996), Electrical conductivity by EC-meter for 1:2.5 soil extract (U.S. Salinity Laboratory Staff, 1954), total carbonate content by calcimeter (Loeppert and Suarez, 1996). In addition to nitrogen analysis by Kjeldahl procedure (Kjeldahl, 1883), phosphorous by Olsen Method (Olsen and Sommers, 1982), Potassium and sodium, by emission flame photometry (Thomas, 1982), calcium, and magnesium by titrimetric method (Cheng and Bray, 1951), and Sodium Adsorption Ratio determined by calculation from calcium, magnesium, and sodium analysis (Soil Survey Staff, 1999). 


\section{Plantation}

The experimental pots were located in conditioned green house; one seedling was planted in each pot on January 16, 2008. The treatment application was started two weeks after the planting date.

\section{Irrigation and fertilization}

All pots received the same quantity of water as well as fertilizer quantity. The water was applied daily according to the Penman Monteith equation (Allen et al., 1998) to assure no water was drained from the bottom of the pot. All pots received the same fertilizer rate once every two weeks. For initial plant growth stages, urea fertilizer was used, while compound chemical fertilizer 18-18-18 with micronutrient was used for the later stages and determines the total amount of the nutrients added.

\section{Treatment application}

The treatments were started on January 29, 2008 according to previously prepared schedule for the whole season.

The Pentakeep-V stock solution was prepared every week at the time of application, which was added with the irrigation water either as a soil application (rhizosphere) or foliar application, depending on the treatment.

Pentakeep-V was applied according to the experimental concentration treatments. A manual sprayer was used to apply the foliar application with a volume sufficient to wet the whole plant vegetative cover, whereas the same Pentakeep-V amount was used for the soil application (rhizosphere) with the irrigation water.

\section{End of the experiment}

The experiment was ended on June 4, 2008. The plant was cut from the soil surface level point and weighed, plant shoots (leaves and branches) and fruit samples were collected for dry matter determination as well as for chemical lab analysis (Horneck and Miller, 1998; Huang and Schulte, 1985).

During the tomato picks, only the marketable tomato fruit was harvested and weighted. While the green fruit was left on the plant until reaching this red stage.

As fruit quality parameter, the results of fruit average weight as calculated from the number of the total fruit yield and number of fruits.

\section{Results and Discussion}

\section{The effect of Pentakeep-V treatment on Tomato yield parameters}

All Pentakeep-V foliar application treatments as well as two soil application treatment; L1W2 and L1W3 showed higher tomato fruit yield with LSD $=932.3 \alpha=0.05$ (Figure 2).

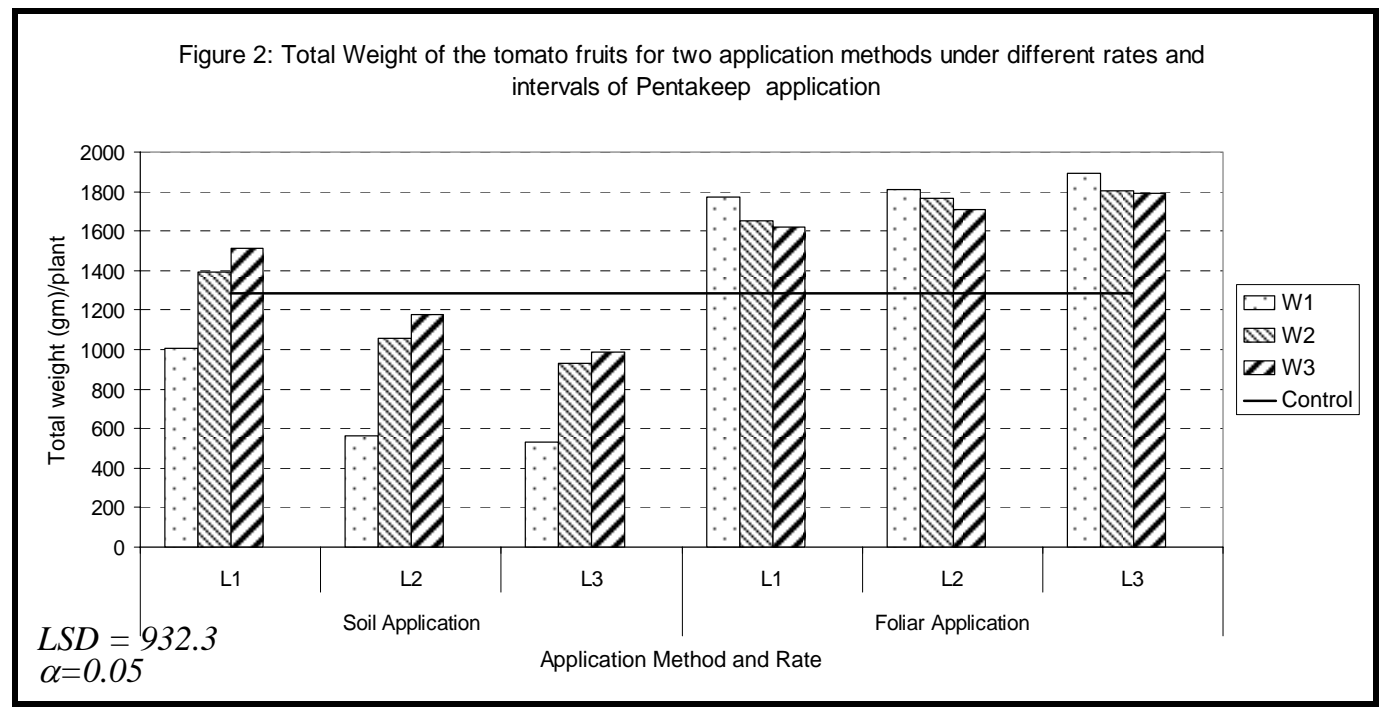


Foliar treatment of L3W1 and L2W1 showed the highest significant $(\alpha=0.05)$ yield that gave about $146 \%, 140 \%$, respectively, compared to the control treatments as shown in Table 1. Results showed the foliar method of application produced more yield (1757 g) compared to the soil application treatments (1017 g), which support the former mentioned chemical results that revealed better nutrient situation for the foliar application.

Table 1. Tomato yield percentage of the Pentakeep-V application treatment compared to control treatment $\left(\operatorname{LSD}_{\alpha=0.05}=72.4\right)$.

\begin{tabular}{lllllll}
\hline & \multicolumn{2}{l}{ Soil application } & \multicolumn{4}{l}{ Foliar application } \\
Weeks & L1 & L2 & L3 & L1 & L2 & L3 \\
\hline W1 & 78.23 & 43.90 & 41.54 & 137.68 & 140.79 & 146.86 \\
W2 & 107.93 & 82.03 & 72.23 & 128.11 & 137.14 & 140.36 \\
W3 & 117.68 & 91.38 & 76.62 & 125.98 & 132.65 & 139.18 \\
\hline
\end{tabular}

As fruit quality parameter, The results of fruit average showed the highest fruit average weight obtained from L3W3 foliar application treatment, where most of the experiment treatment showed larger fruit size rather than control treatment except L1W1 and L3W3 under soil application (Figure 3).

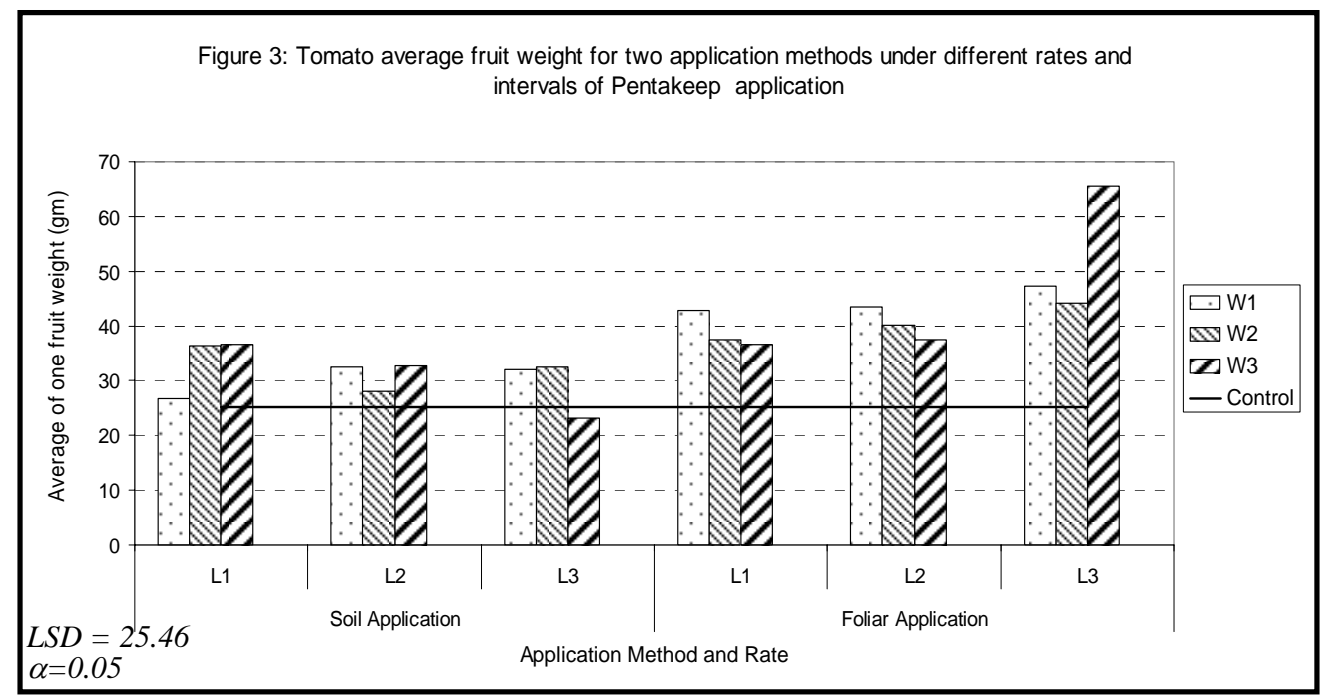

The impact of treatment on the tomato shoot weight (leaves and branches) shown in Figure 4. Results showed more vegetative growth with foliar applications as compared to soil application treatments with significant differences. LSD $=365.8$ $(\alpha=0.05)$

Tomato root weight followed a similar trend to yield (Table 2). The root weight for soil application treatment is less than foliar treatment and control as well. But some of the foliar treatment showed higher root weight than control, this might be due to some negative effects of Pentakeep-V on the soil characteristics and the nutrient interaction. 


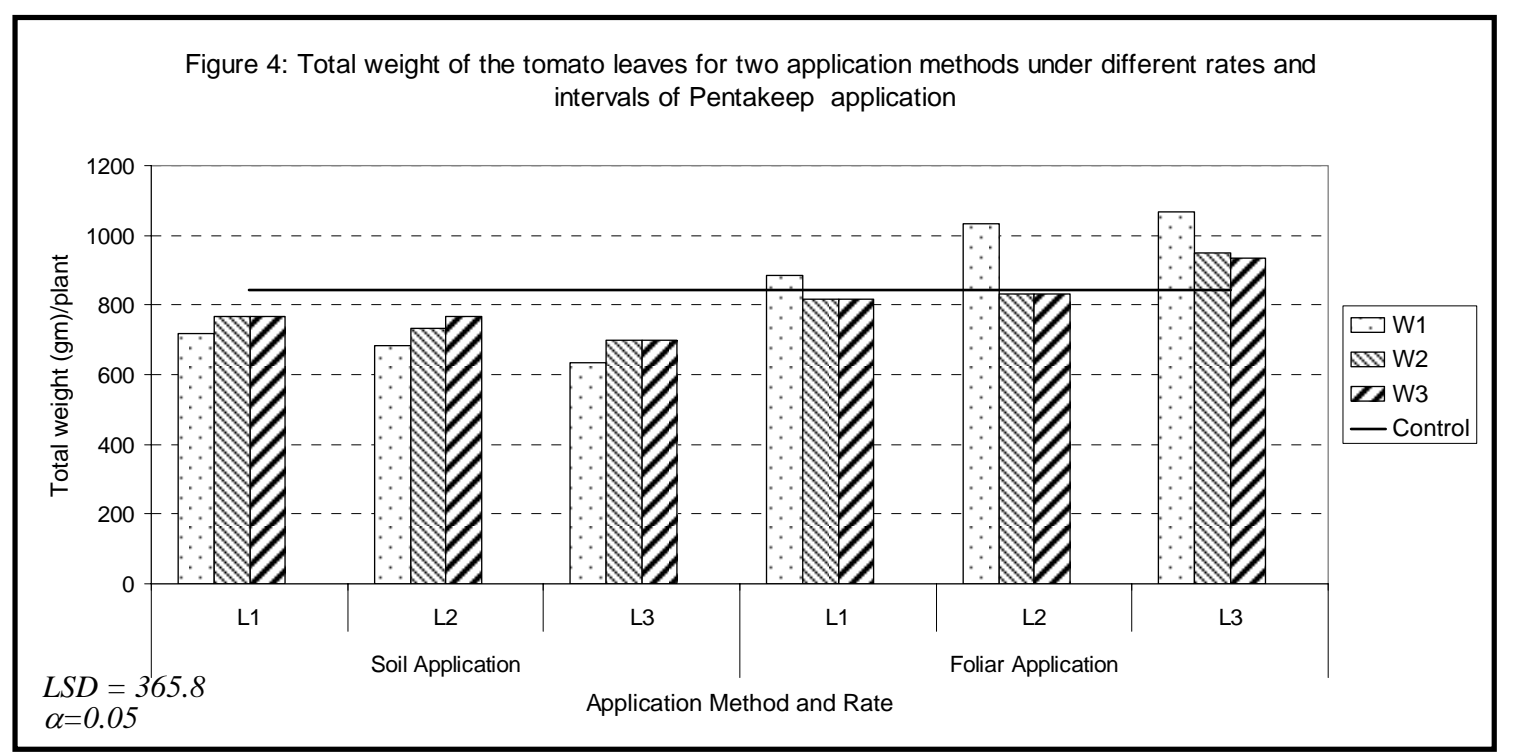

Table 2. A percentage ratio for tomato root weight of the Pentakeep-V application treatment compared to control treatment $\left(\operatorname{LSD}_{\alpha=0.05}=53.1\right)$.

\begin{tabular}{lllllll}
\hline & \multicolumn{3}{l}{ Soil application } & \multicolumn{4}{l}{ Foliar application } \\
Weeks & L1 & L2 & L3 & L1 & L2 & L3 \\
\hline W1 & 78.85 & 68.56 & 66.60 & 99.10 & 120.31 & 132.58 \\
W2 & 85.80 & 80.32 & 71.49 & 88.46 & 96.08 & 119.04 \\
W3 & 85.84 & 83.44 & 77.33 & 88.03 & 93.65 & 99.63 \\
\hline
\end{tabular}

Dry matter results of different tomato parts showed significant differences in case of fruit, shoot and roots. Figure 5 shows the results of fruit dry matter. The figure describes high significant dry matter percentage (less water percentage) for soil application treatment compared to foliar treatments.

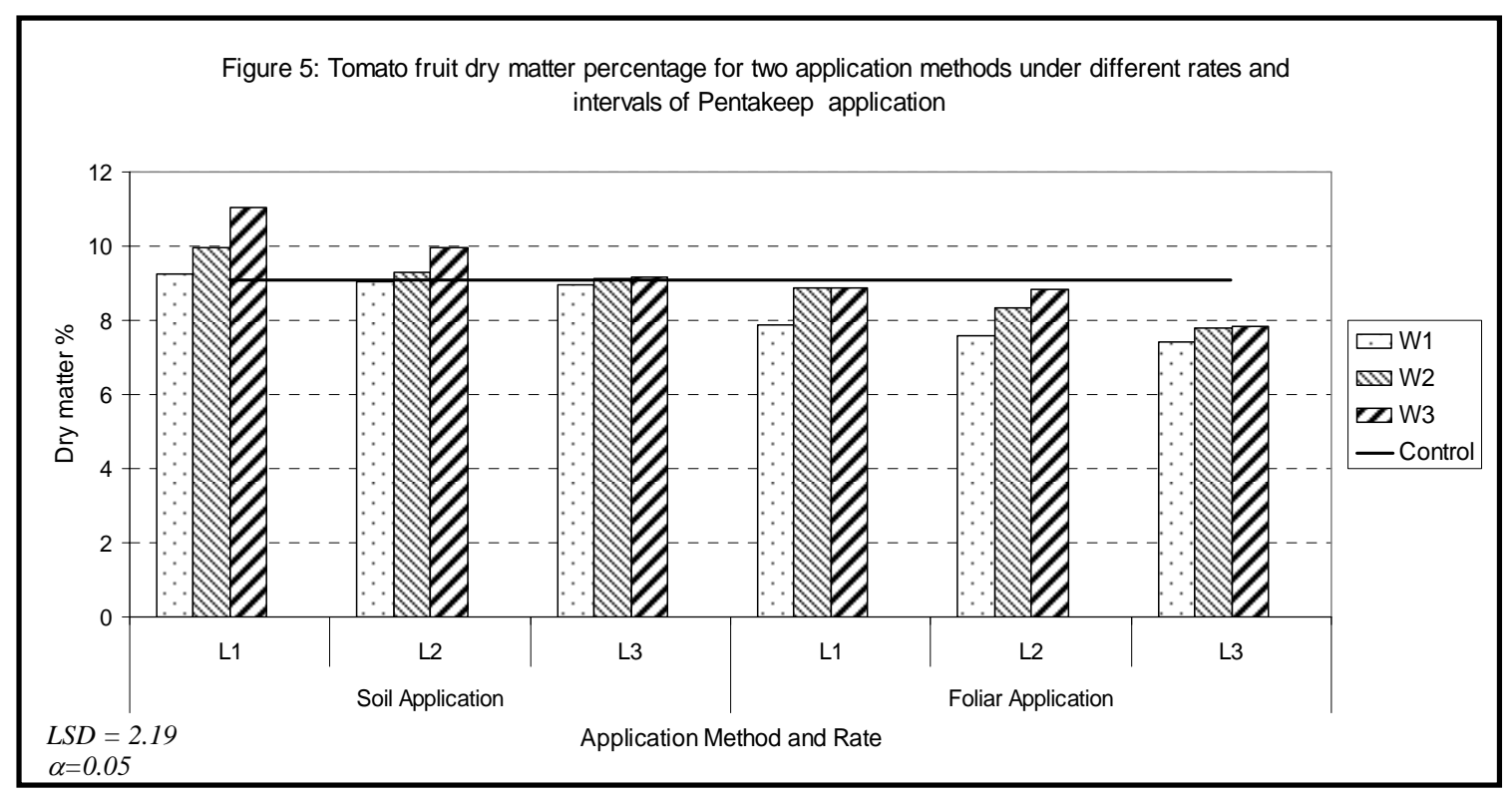


The same trend was obtained for tomato leaves dry matter that results on higher significant dry matter percentage for soil application as compared to the foliar method; this result quite reflects the crop water absorption was higher in the foliar treatments. This result proves the company hypothesis that one of the Pentakeep-V action on the stomata opening that leads of course for more water absorption (more evapotranspiration) and yield. Roots dry matter percentage had shown relatively the same trend as in the leaves. Table 3 shows the percentage ratio for tomato leaves dry matter as compared to control. The foliar application treatment showed a dry matter almost less than control treatments (water content is more), while the dry matter for soil application treatments might be explained by the effect of the treatment on soil salinity as compared to control which affects the soil osmotic potential and accordingly affects the water absorption. This explanation goes with the tomato root dry matter that showed the same trend.

Table 3. A Percentage ratio for tomato leaves dry matter for different Pentakeep-V application treatment as compared to control $\left(\mathrm{LSD}_{\alpha=0.05}=16.2\right)$.

\begin{tabular}{lllllll}
\hline & \multicolumn{3}{l}{ Soil application } & \multicolumn{4}{l}{ Foliar application } \\
Weeks & L1 & L2 & L3 & L1 & L2 & L3 \\
\hline W1 & 110.62 & 103.85 & 102.72 & 98.79 & 97.48 & 89.49 \\
W2 & 112.95 & 110.77 & 105.40 & 101.56 & 99.51 & 98.09 \\
W3 & 116.34 & 111.75 & 107.20 & 102.18 & 99.85 & 98.21 \\
\hline
\end{tabular}

\section{Effect of Pentakeep-V treatment on soil physical properties}

The results showed a significant increase for the moisture content at a field capacity point for treatment L2W1 and L3W2 with foliar application with 18.5 and $18.46 \%$, respectively, compared to $16.56 \%$ for the control treatment.

The foliar application affect the stomata opening and the photosynthesis rate with no any negative effect on the soil characteristics, while the soil application treatments showed some negative effects on the chemical soil characteristic which affect the availability of some nutrients.

Wilting point percentage represents the lower limit for the available water, results also showed a slightly significant (with very narrow means) difference that varied from about $5 \%$ for treatment L3W3 foliar application to $9.56 \%$ for L1W2 soil application compared to $7.17 \%$ for control treatment.

The field capacity percentage increased and wilting point decreased, which means an increase in available water for plant growth. this might be due to the negative effect of the soil application on soil characteristic The results of the field capacity and wilting point were used to calculate the plant available water (Figure 6), treatment L3W2 foliar application showed the highest significant available water that reached to $132.73 \mathrm{~mm} / \mathrm{m}$, which is about $140 \%$ of the control treatment. 


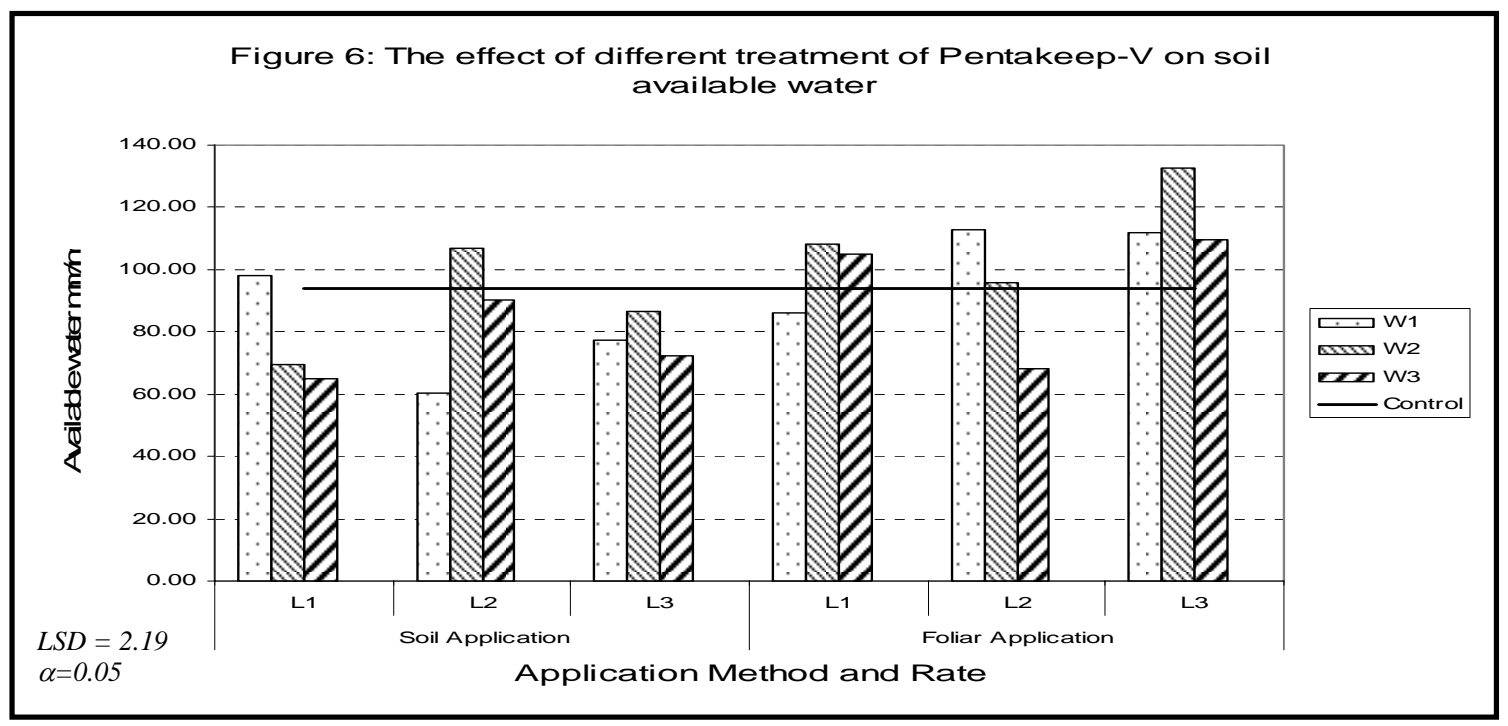

The soil bulk density was decreased to $1.16 \mathrm{gm} / \mathrm{cm}^{3}$ (improved due to increase in the soil volume) with significant difference for L3W1 foliar application with no significant difference with other treatments except L1W3 soil application with bulk density $1.39 \mathrm{gm} / \mathrm{cm}^{3}$ compared to $1.25 \mathrm{gm} / \mathrm{cm}^{3}$ for control treatment. Results of bulk density are shown in Figure 7.

The results of the physical properties could be explained by variation in the soil pore size distribution with reaction to the treatments.

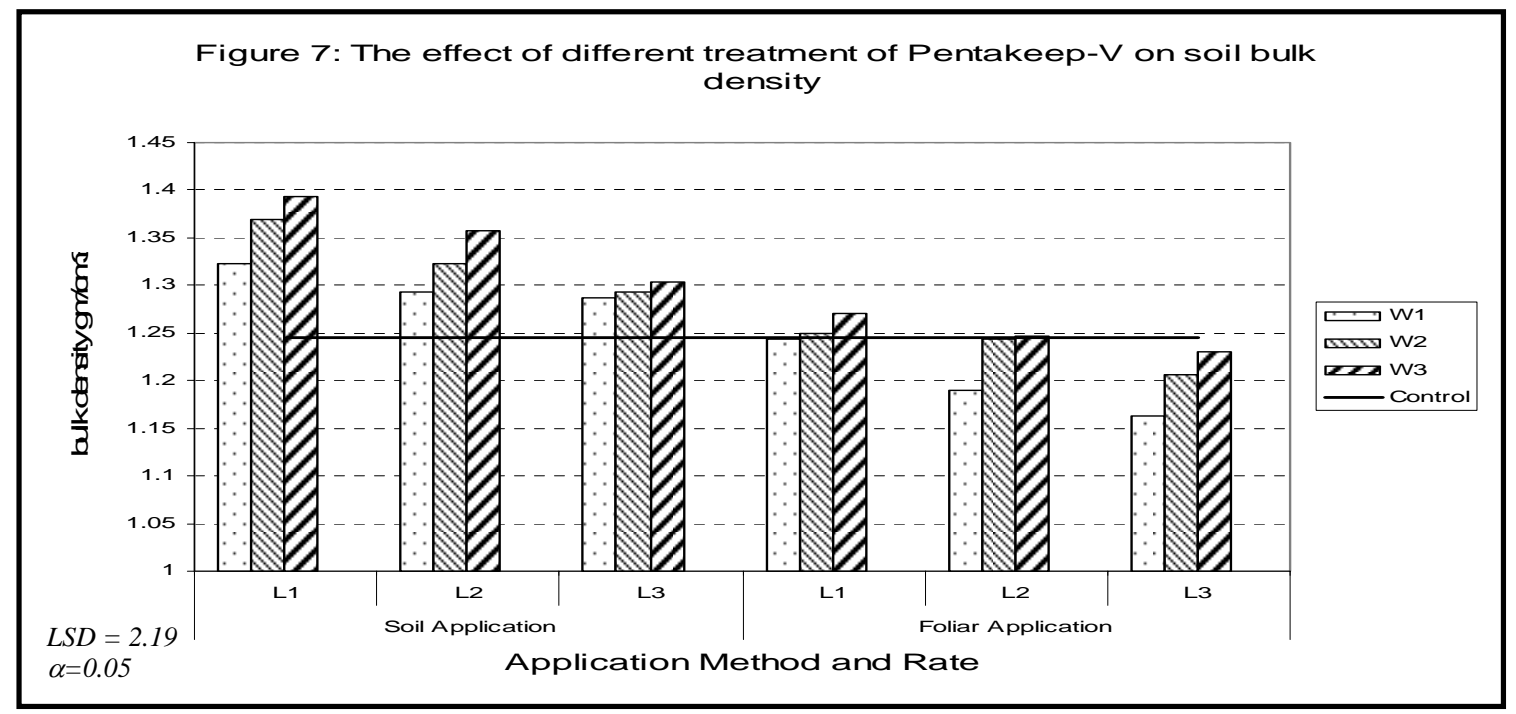

\section{Effect of Pentakeep-V treatment on soil chemical properties}

The results of the soil $\mathrm{pH}$ in Figure 8 showed a significant increase in soil $\mathrm{pH}$ for the soil application treatments compared to control most of the foliar application treatments showed lower $\mathrm{pH}$ value than control treatment. This is due to the alkaline effect of Pentakeep- $\mathrm{V}$ on soil.
Figure 9 shows the results of soil electrical conductivity (EC) that represents the effect of the treatment application on soil salinity level.

Results showed a significant $(\mathrm{LSD}=$ $1.39 \alpha=0.05)$ increase of the soil EC for the treatment of soil application as compared to foliar. 

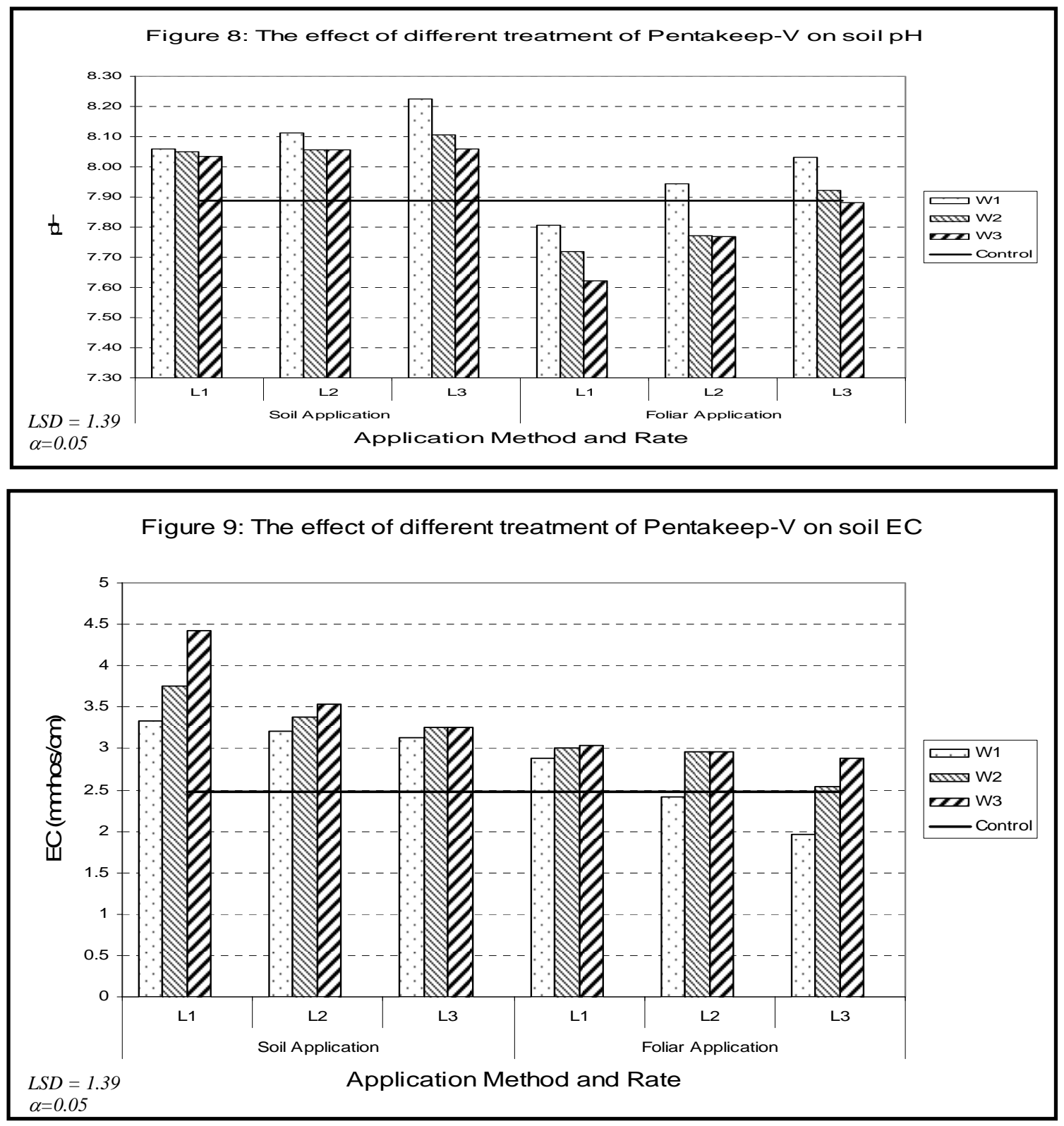

Soil carbonate content showed almost the same trend as EC that match with the $\mathrm{pH}$ results with high significant carbonate content for soil application and compared to less carbonate for foliar application treatment. The percentage of total carbonate as compared to the control treatment is shown in Table 4. Results of total soil carbonate for all foliar treatments showed less or almost same as control treatment, whereas the soil application treatments showed higher total carbonate than control treatments.

Table 4. Percentage of soil total carbonate of the Pentakeep-V application treatment compared to control treatment $\left(\mathrm{LSD}_{\alpha=0.05}=10.6\right)$.

\begin{tabular}{lllllll}
\hline & \multicolumn{3}{l}{ Soil application } & \multicolumn{4}{l}{ Foliar application } \\
Weeks & L1 & L2 & L3 & L1 & L2 & L3 \\
\hline W1 & 101.81 & 116.48 & 116.51 & 95.78 & 98.20 & 98.63 \\
W2 & 99.20 & 101.36 & 107.25 & 93.94 & 94.03 & 97.38 \\
W3 & 98.85 & 99.41 & 106.39 & 93.15 & 94.00 & 96.07 \\
\hline
\end{tabular}


Results showed that SAR value increases in soil application treatments compared to foliar treatments that have values close to the control treatment. These results could be explained due to the high sodium concentration in the Pentakeep-V product in addition to the soil reaction $\mathrm{pH}$ and soil carbonate results. Figure 10 shows the SAR results for the Pentakeep treatments and the control treatment. One can obviously conclude from the figure the soil application treatment showed a higher SAR value compared to the control, whereas the foliar application treatment showed value around the control treatment.

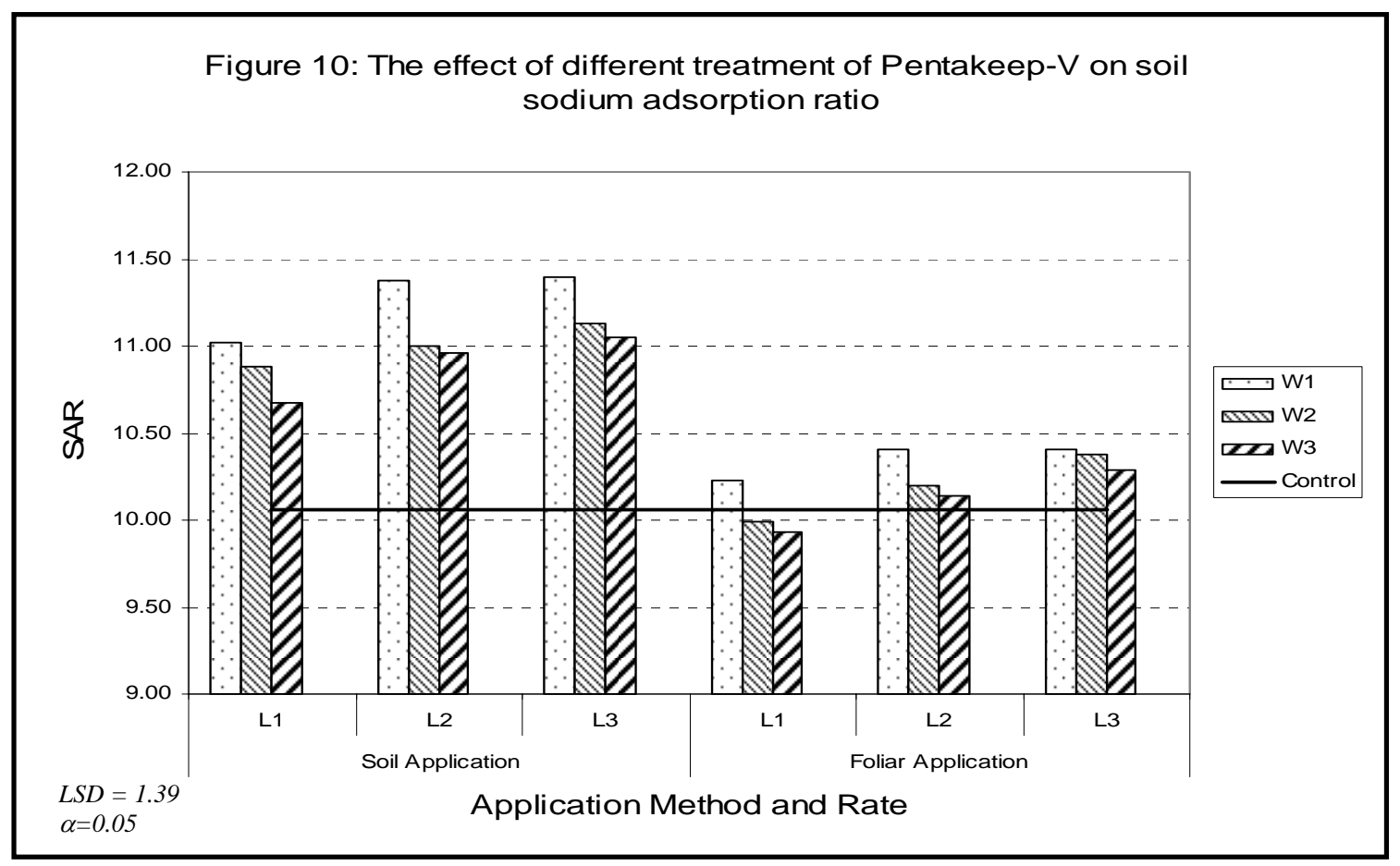

\section{The effect of Pentakeep-V treatment on tomato nutrients uptake}

The plant nutrients uptake reflects the nutrient availability and nutrient interaction as well as fertilizer use efficiency; the highest ratio of the nutrient in the plant part indicates high nutrient availability for plant nutrient absorption.

\section{In roots}

Results of the nitrogen concentration in tomato roots showed a significant increase for the soil application treatment compared to the foliar application treatment that showed less content than control treatment.

The phosphorus proportion in the tomato root shown in Figure 11 that illustrates low amount of $\mathrm{P}$ in root under soil application treatment compared to foliar application and control treatment. This might be due to the $\mathrm{pH}$ effect of the Pentakeep-V on the soil that decreases the $P$ availability in the soil.

The potassium results showed the same trend as phosphorus uptake in the roots. Also micronutrient results showed the same trend that showed less nutrient amount in root for the soil application treatment compared to more nutrient proportion in case of foliar application. These results could be combined with the $\mathrm{pH}$ value that increased in case of soil application, which creates undesirable condition for micronutrient availability. 
Emir. J. Food Agric. 2010. 22 (3): 174-188

http://ffa.uaeu.ac.ae/ejfa.shtml

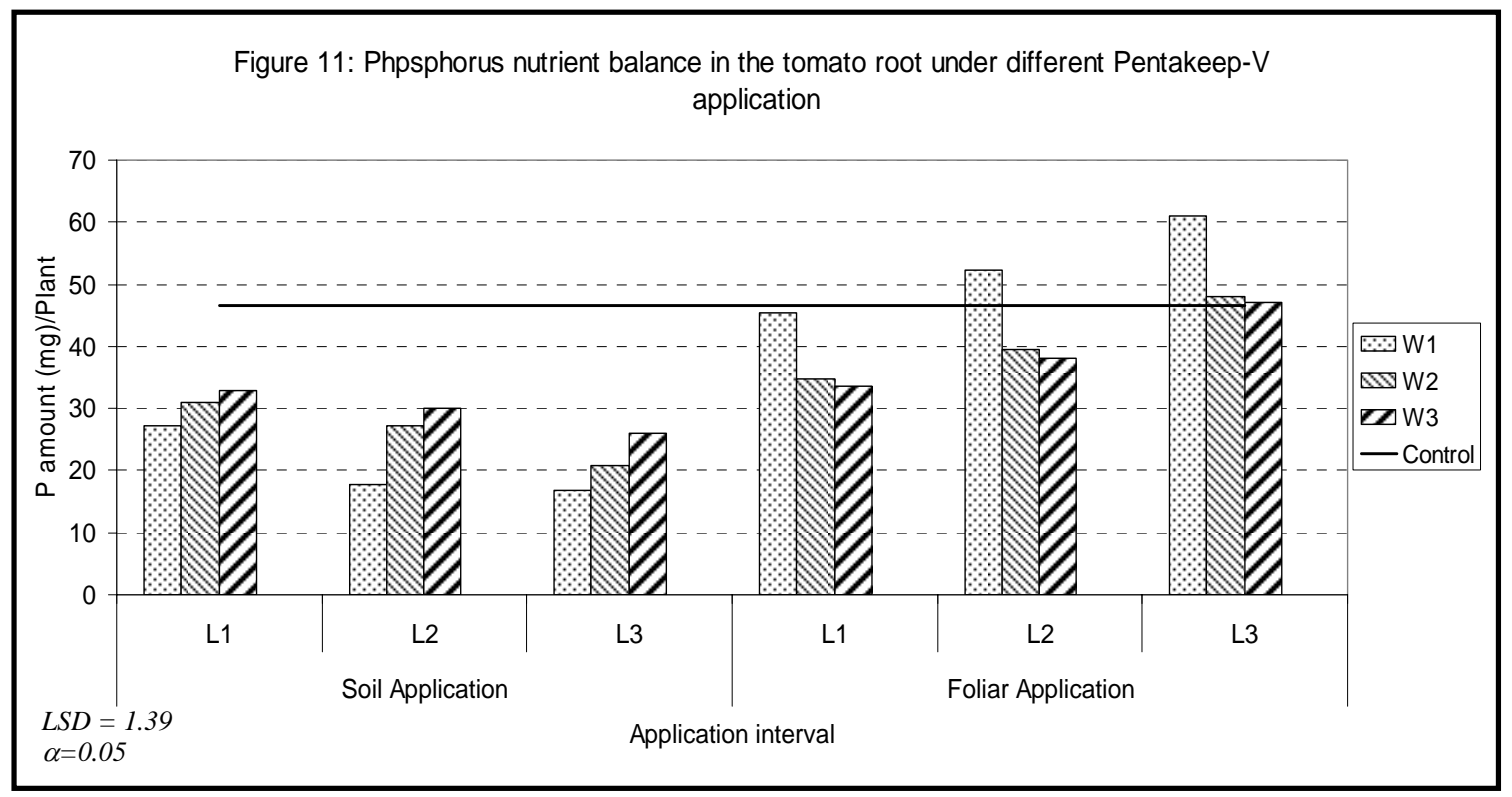

\section{In Leaves}

Results for treatment L3W1 soil application showed the highest significant nitrogen uptake in tomato shoot (branches and leaves) whereas foliar application treatment showed less nitrogen uptake in tomato shoot as compared to the control treatment (Figure 12).

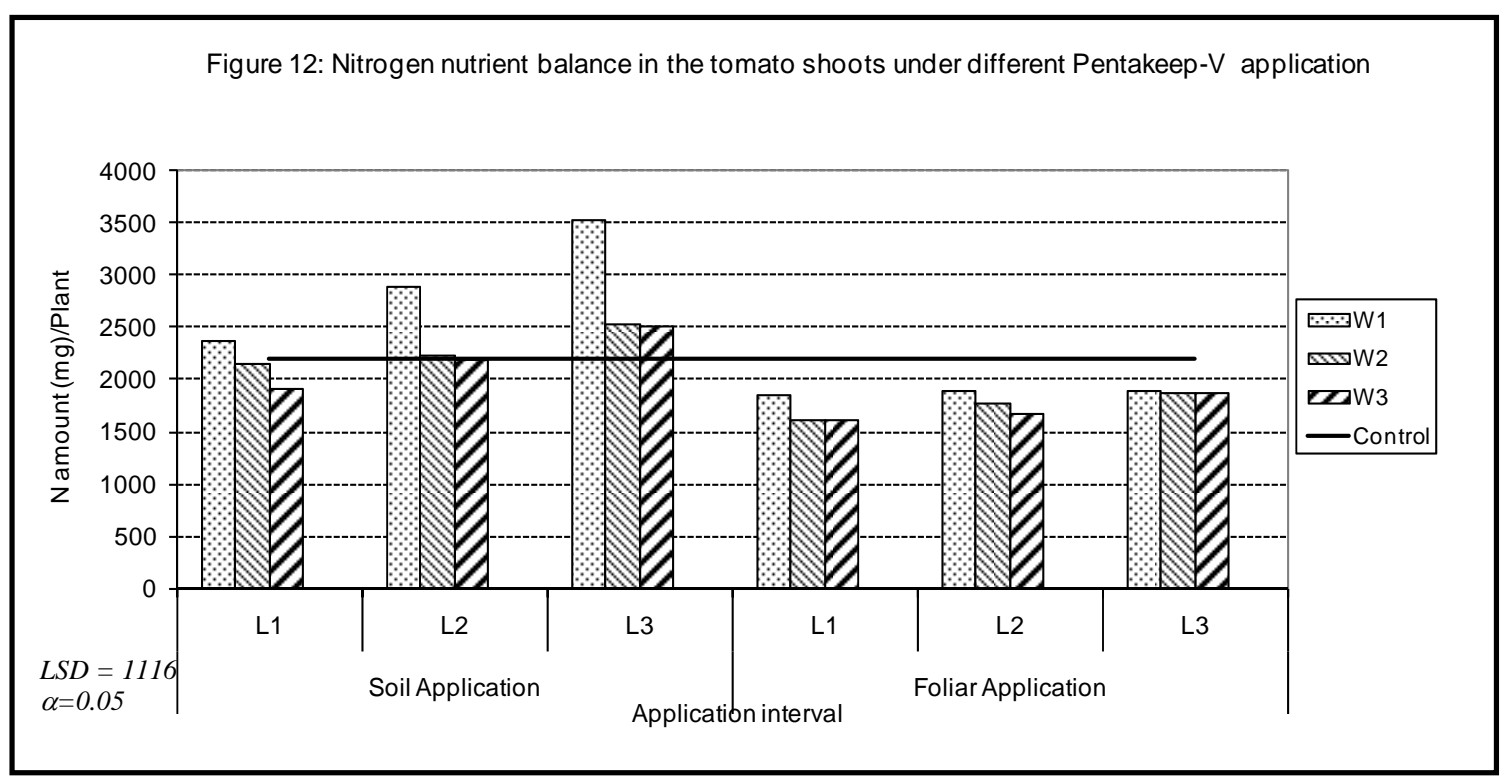

Phosphorus uptake in tomato shoots showed a reverse trend as in case of nitrogen, where the phosphorus uptake is higher in foliar treatment as compared to soil treatments, that due explain the more $\mathrm{P}$ availability under foliar compared to soil treatments, since the soil $\mathrm{pH}$ increased under soil treatments that leads to more $\mathrm{P}$ fixation. Also the phosphorus uptake for soil application treatment showed a decreasing trend as increase in Pentakeep$\mathrm{V}$ addition (Figure 13). 


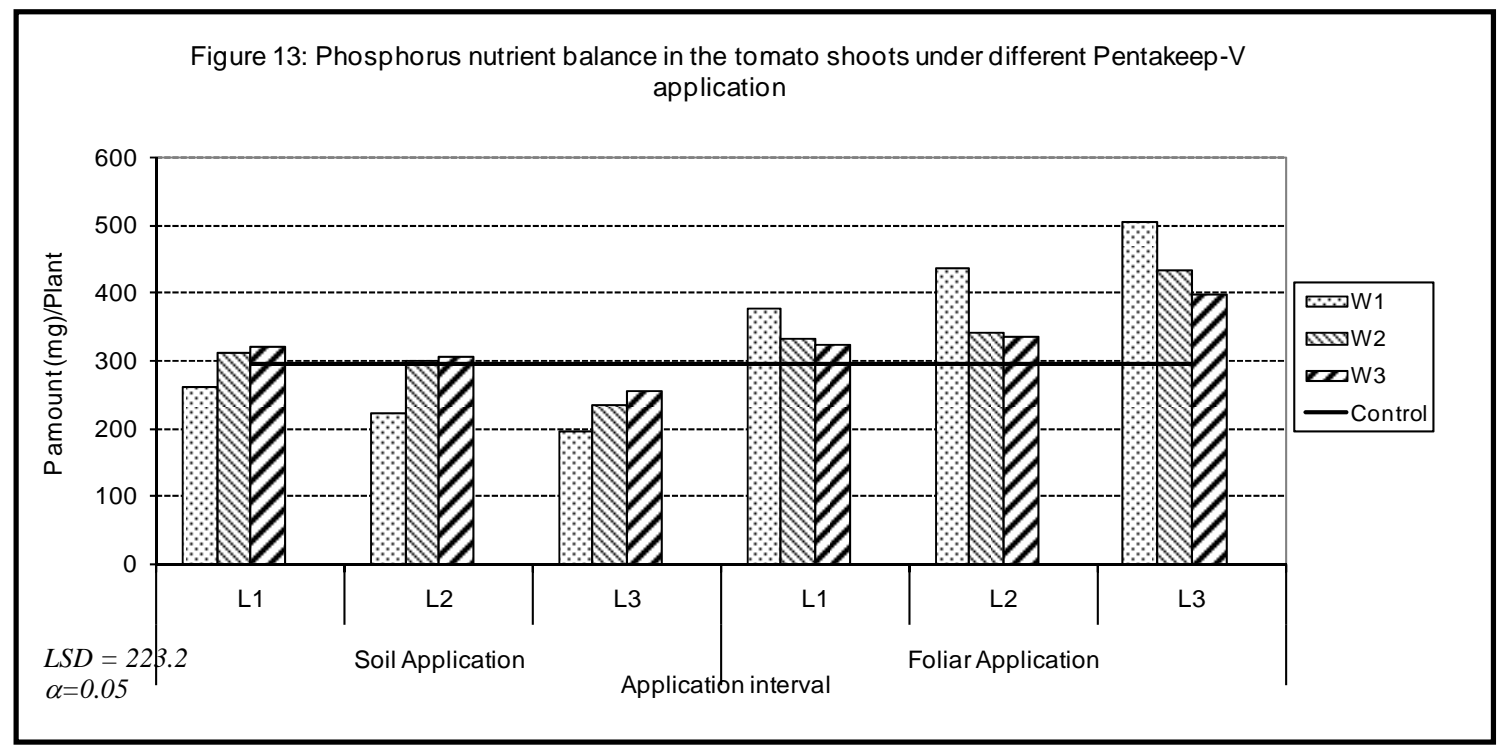

The results of potassium uptake in tomato shoot illustrated low $\mathrm{K}$ in shoots with soil application treatment compared to foliar application and control treatment.

Copper shoot uptake showed lower values than control except in two treatments, L2W1, and L3W1 foliar application, where L3W1 foliar application showed the highest significant cupper content. Generally, the cupper proportion in the shoots showed higher value for the foliar treatment compared to soil application treatment.

Results showed that the Iron quantity in tomato shoots for most soil application treatment is lower than the control treatment, whereas it was more in foliar application treatments as compared to the control.

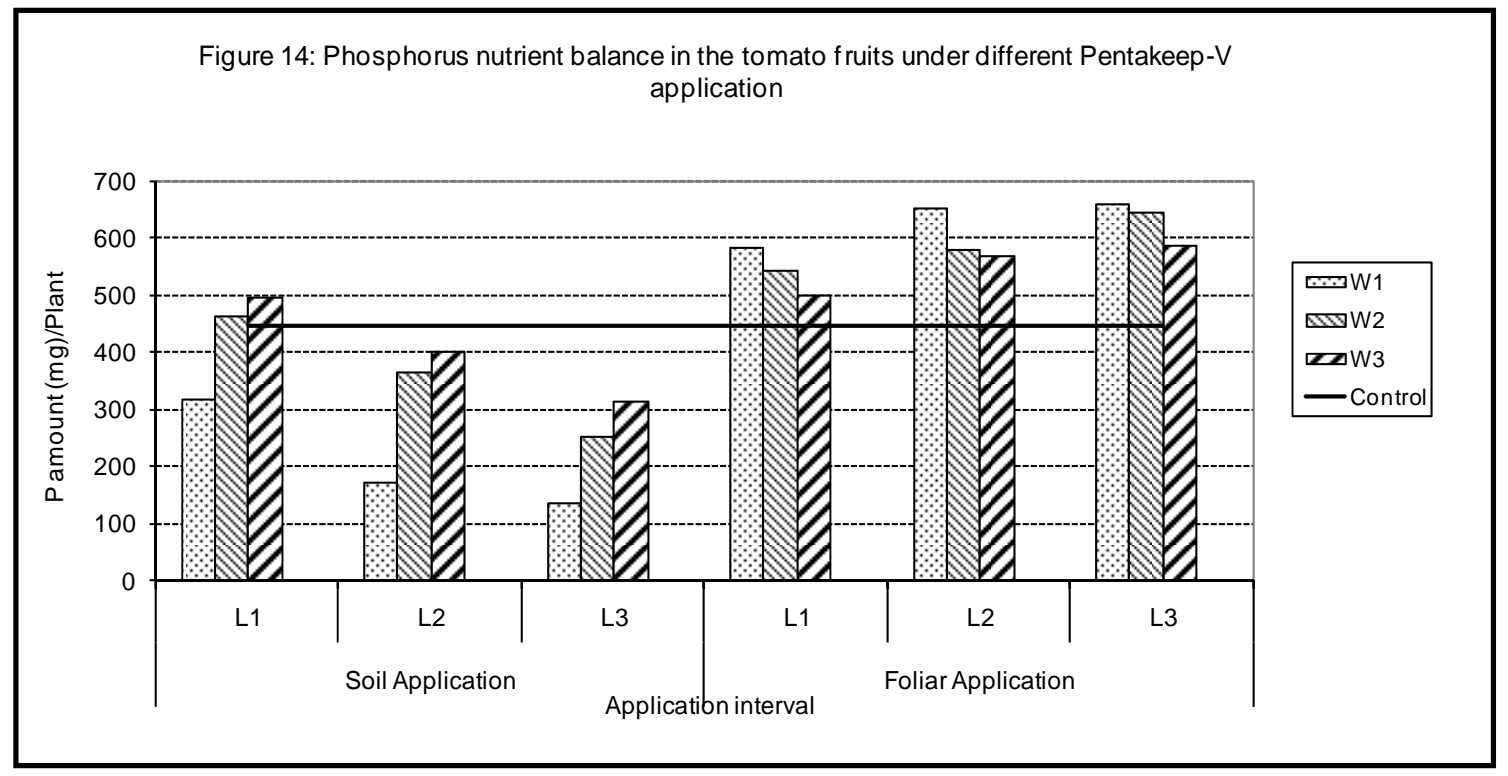

Treatment of L3W1 foliar application showed the highest significant leave manganese and zinc content, with higher value for foliar treatments compare to soil application treatment. Table 5 shows the micronutrient percentage amount in tomato shoot as compared to the control treatment. 
Emir. J. Food Agric. 2010. 22 (3): 174-188

http://ffa.uaeu.ac.ae/ejfa.shtml

Table 5. Percentage of tomato leave micronutrient amount with relative to control treatment.

\begin{tabular}{|c|c|c|c|c|c|c|}
\hline \multirow[t]{2}{*}{ Method } & \multirow[t]{2}{*}{ Level } & \multirow[t]{2}{*}{ Interval } & \multicolumn{4}{|c|}{$\begin{array}{l}\text { Percentage of leaves nutrient weight as compared } \\
\text { to control treatment }\end{array}$} \\
\hline & & & $\mathbf{C u}$ & $\mathrm{Fe}$ & Mn & Zn \\
\hline \multirow{9}{*}{ Foliar } & \multirow{3}{*}{ L1 } & W1 & 92.43 & 122.56 & 117.76 & 206.38 \\
\hline & & W2 & 88.80 & 111.77 & 108.44 & 125.22 \\
\hline & & W3 & 66.62 & 109.96 & 108.18 & 116.81 \\
\hline & \multirow{3}{*}{ L2 } & W1 & 99.25 & 159.06 & 126.68 & 131.39 \\
\hline & & W2 & 89.77 & 118.94 & 115.22 & 128.01 \\
\hline & & W3 & 89.48 & 113.16 & 109.65 & 125.68 \\
\hline & \multirow{3}{*}{ L3 } & W1 & 86.60 & 160.08 & 132.78 & 169.59 \\
\hline & & W2 & 80.49 & 155.37 & 126.01 & 151.38 \\
\hline & & W3 & 96.36 & 136.95 & 118.79 & 136.95 \\
\hline \multirow{9}{*}{ Soil } & \multirow{3}{*}{ L1 } & W1 & 77.85 & 98.07 & 95.12 & 94.55 \\
\hline & & W2 & 81.99 & 107.94 & 103.86 & 109.43 \\
\hline & & W3 & 84.66 & 108.23 & 104.88 & 111.71 \\
\hline & \multirow{3}{*}{ L2 } & W1 & 68.63 & 87.77 & 75.64 & 87.08 \\
\hline & & W2 & 98.14 & 99.07 & 97.95 & 96.18 \\
\hline & & W3 & 80.82 & 106.95 & 100.51 & 104.42 \\
\hline & \multirow{3}{*}{ L3 } & W1 & 107.53 & 79.28 & 71.84 & 78.43 \\
\hline & & W2 & 74.34 & 87.92 & 84.17 & 89.30 \\
\hline & & W3 & 76.04 & 91.87 & 94.39 & 92.18 \\
\hline $\operatorname{LSD}_{\alpha=0.05}$ & & & 42.6 & 67.9 & 45.0 & 72.7 \\
\hline
\end{tabular}

\section{In Fruits}

Tomato fruits analysis showed more nitrogen is found in soil application treatments as compared with foliar application with significant difference. While the phosphorus analysis showed a quite opposite trend, in which the foliar application treatments showed fruit phosphorus content more than control treatment, where the soil application treatments showed less significant phosphorus content compared to the foliar application. Figure 14 shows the average phosphorus content in tomato fruits.

The same phosphorus trend had been shown for the potassium quantity in the tomato fruit, but all treatment showed value less than control treatment except in L2W1 and L3W1 under foliar application that showed an increase in potassium fruit amount reaches to about $4 \%$ and $15 \%$ respectively as compared to the control treatment.

The results showed a higher significant micronutrient amount in tomato fruits for the foliar application treatment as compared to soil treatments, less micronutrient tomato fruit for soil application treatment as compared to the control treatment, that means a negative response for soil application treatment regarding the micronutrient accumulation in tomato fruit.

\section{Conclusions}

The Penetakeep-V application showed a significant increase in the tomato fruit yield reached to $146 \%$ compared to control treatments.

All foliar treatments showed less dry matter in the tomato fruit, shoot and roots compared to soil application but with no significant difference.

Results showed a significant negative tendency for the nutrient availability using soil application treatment compared to the foliar especially in case of phosphorus and micronutrient. This trend goes with the $\mathrm{pH}$ results to some extent with the known rules of nutrient interaction. 
Short term studies for the change in soil physical properties might not lead to solid results, like these studies need longterm studies to see the real effect over long time.

Although result showed a deficit trend in some nutrient as affected by treatment but results also showed that deficit wasn't affecting negatively on the production. This could be explain based on the Law of Minimum (Liebig's Law) that states that yield is proportional to the amount of the most limiting nutrient, whichever nutrient it may be in other way if one crop nutrient is missing or deficient, plant growth will be poor, even if the other elements are abundant. Based on that, and since the yield wasn't affected so any deficit in the nutrient balance that decreases the nutrient availability wasn't reached to the deficient level to have a negative effect on the yield.

Based on the yield results, L3W1 Foliar application is recommended treatment that should be adapted in UAE soil.

\section{References}

Allen, R. G., L. S. Pereira, D. Raes and M. Smith. $\quad 1998$ Crop Evapotranspiration: Guidelines for Computing Crop Water Requirements. FAO Irrig. and Drain. Paper 56, 300 p., FAO, Rome.

Blake, G. R. and K. H. Hartge. 1986. Bulk density. In: A. Klute (Ed.) pp. 363382. Methods of soil analysis. Part 1. Physical and mineralogical methods. $2^{\text {nd }}$ Ed. Agron. Monograph 9. ASA and SSSA, Madison, WI.

Cheng, K. L. and R. H. Bray. 1951. Determination of calcium and magnesium in soil and plant material. Soil Sci. 72:449-458.

Horneck, A. and O. Miller. 1998. Determination of total nitrogen in plant tissue. In: Y. P. Kalra (Ed.)
Handbook and Reference Methods for Plant Analysis. CRC Press, New York.

Hotta, Y., T. Tanaka, H. Takaoka,Y. Takeuchi and M. Konnai. 1997. Promotive effects of 5-aminolevulinic acid on the yield of several crops. Plant Growth Regul. 22:109-114.

Huang, Chao-Yong Luh and E. E. Schulte. 1985. Digestion of Plant Tissue for Analysis by ICP Emission Spectroscopy. Commun. Soil Sci. Plant Anal. 16(9):943-958.

Kjeldahl, J. 1883. Neue Methode zur Bestimmung des Stickstoffs in organischen Korpern. Z. Anal. Chem. 22:366-382.

Loeppert, R. H. and D. L. Suarez. 1996. Carbonate and gypsum. In: D. L. Sparks (Ed.) pp. 437-474. Methods of Soil Analysis. Part III Chemical Methods. SSSA Book Ser 5 SSSA and ASA, Madison, WI.

Olsen, S. R. and L. E. Sommers. 1982. Phosphorus. In: A. L. Page, R. H. Miller and D. R. Keeney (Eds.) pp. 403-430. Methods of Soil Analysis. Part 2. Chemical and microbiological properties. $2^{\text {nd }}$ Ed. Agron. Monogr. 9. ASA and SSSA, Madison, WI.

Smaling, E., Stoorvogel and P. Windmeijer. 1993. Calculating soil nutrient balances in Africa at different scales II. District Scale. Fertilizer Res. 35:237-250.

Soil Survey Staff. 1999. Soil Taxonomy: A basic system of soil classification for making and interpreting soil surveys. USDA-NRCS Agric. Handb. 436. $2^{\text {nd }}$ Ed. U.S. Govt. Print. Office, Washington, DC. 
Thomas, G. W. 1982. Exchangeable cations. In: A. L. Page, R. H. Miller, and D. R. Keeney (Eds.) pp. 159-165. Methods of Soil Analysis. Part 2. Chemical and Microbiological Properties. $2^{\text {nd }}$ Ed. Agron. Monogr. 9. ASA and SSSA, Madison, WI.

Thomas, G. W. 1996. Soil $\mathrm{pH}$ and soil acidity. In: D. L. Sparks (Ed.) pp. 475-490. Methods of Soil Analysis. Part 3. Chemical Methods. No. 5. ASA and SSSA, Madison, WI.

Topp, G. C., Y. T. Galganov, B. C. Ball and M. R. Carter. 1993. Soil water desorption curves. In: M. R. Carter (Ed.) pp. 569-579. Soil Sampling And Methods of Analysis. Can. Soc. Soil Sci., CRC Press, Boca Raton, FL.

U. S. Salinity Laboratory Staff. 1954. L. A. Richards (Ed.) p.160. Diagnosis and improvement of saline and alkali soils. USDA Handb. 60. U.S. Govt. Print. Office, Washington, DC.

Weissbach F. and P. Ernst. 1994. Nutrient budgets and farm management to reduce nutrient emissions. Proc. $15^{\text {th }}$ General Meeting of Environmental Grassland Federation, 343 - 359. 